\title{
Oral Corrective Feedback: Examining Teacher- Initiated Correction of CFL (Chinese as a Foreign
}

\section{Language) Learners' Pronunciation Errors}

\author{
Julia Renner
}

\begin{abstract}
This paper examines oral corrective feedback strategies in regard to pronunciation errors in a Chinese foreign language classroom. Traditional oral corrective feedback typologies (Lyster and Ranta 1997; Ellis and Sheen 2006; Sheen 2011) have been combined with Chinese pronunciation teaching methods and investigated in a case study conducted at the Department of East Asian Studies, University of Vienna. Two sessions of first year Chinese language laboratory classes were observed and recorded. The qualitative data analysis was carried out in two stages. First, traditional oral corrective feedback typologies were applied to the collected material in order to find out which types of corrective feedback were used (deductive analysis). The results revealed that corrective feedback on pronunciation errors are mostly given in an explicit manner. Therefore, as a second step, a differentiated typology of explicit correction was developed (inductive analysis). The main findings of this study are that pronunciation errors in a Chinese foreign language classroom are corrected explicitly and treated with methods of 1) explication, 2) comparison, and 3) reduction. The explicitness of these methods is further enhanced by 1) paralinguistic cues (stress, speech rate modification), 2) visualisations (gestures) and 3) additional verbalisation.
\end{abstract}

Keywords: Teaching Chinese as a Foreign Language, Corrective Feedback, Chinese Pronunciation, language laboratory

prae

sens

Renner, Julia. "Oral Corrective Feedback: Examining Teacher-Initiated Correction of CFL (Chinese as a Foreign Language) Learners' Pronunciation Errors." In Vienna Journal of East Asian Studies, Volume 7, eds. Rudiger Frank, Ina Hein, Lukas Pokorny, and Agnes Schick-Chen. Vienna: Praesens Verlag, 2015, pp. 197-226. https://doi.org/10.2478/vjeas-2015-0007 


\section{Introduction}

Learners of Chinese as a foreign language (CFL) face two major challenges during the initial stage of their study: coping with a new writing system and acquiring a new phonetic system with syllable tones, as Mandarin Chinese is a tone language. Besides certain sounds, e.g. retroflex consonants /zhi/, /chi/, /shi/ and palatal consonants $/ \mathrm{ji} /$, /qi/, /xi/, syllable tones by themselves as well as in conjunction with the prosodic properties of spoken language, such as stress and intonation, are a major challenge for learners and teachers of CFL. In Mandarin Chinese the functional load of syllable tones is comparable to the functional load of vowels, which means that for successful communication the identification of syllable tones is just as important as the identification of vowels (Surendran and Levow 2004). These circumstances render pronunciation instruction and corrective feedback in CFL classrooms of paramount importance.

With Craig Chaudron's (1988) systematic investigation of learner errors and Pit Corder's ground-breaking essay on The Significance of Learners Errors (1981), scientific research on corrective feedback became a relevant field of applied linguistics. Lyster and Ranta (1997) developed a typology of feedback methods which has been slightly modified by Ellis and Sheen (2006) and is prevalent today in classroom practice and research. Most empirical studies focus on English as a second or foreign language and are aimed at the correction of grammatical errors. There is still a lacuna in research concerning corrective feedback on pronunciation errors, especially in the context of Chinese language acquisition.

Against this background the aim of this paper is to investigate what strategies of corrective feedback teachers apply in order to deal with CFL learners' pronunciation errors. I will first discuss the theoretical framework of corrective feedback, followed by a short outline of corrective feedback in classroom practice and the status quo of pronunciation teaching methods in general and in the case of CFL. In the third part of the paper I will present my own case study which consisted of teacher-initiated corrective feedback on CFL learners' pronunciation errors in language laboratory classes as part of the bachelor programme of Chinese Studies at the University of Vienna.

\section{Oral Corrective Feedback: Theoretical Framework}

Research on corrective feedback traditionally has been carried out within the framework of interaction theory, although more recently the application of sociocultural theory of learning gained significance (Sheen 2011: 9). In this section I will outline the origins of corrective feedback research, followed by a discussion of corrective feedback from an interactionist perspective and a sociocultural perspective. 


\section{The Origins of Corrective Feedback Research: 'Caretaker Talk' and} 'Foreigner Talk'

'Caretaker talk' and 'foreigner talk' are considered two specific language registers marked by modification and simplification of language input (Mackey et al. 2012: 7). 'Caretaker talk' (Ferguson 1977) refers to those language styles parents or adults adopt in order to communicate with babies and children that are still in an early stage of language acquisition. The main aspects include simplification of language, redundancy, and being grammatically overly correct (Ellis 1994: 251). Studies were able to prove that adults speak with a higher pitch, reduce the speech rate or support verbal input with gestures in order to make their input more salient and therefore facilitate communication (Ferguson 2004: 183).

In the 1970s, research began to focus on 'foreigner talk' between native speakers and non-native speakers. The main concern was to investigate native-speaker - nonnative-speaker conversations and in particular how native-speakers modify language in order to facilitate communication with less competent speakers (Mackey et al. 2012: 7). Two main strategies have been identified: input-modification, e.g. omitting connective words, and interactional modification, which is divided further into 'discourse management' and 'discourse repair'. Discourse management refers to different strategies to clarify the topic of communication, consideration of quantitative and qualitative aspects of information, temporal frame, checking-back and the repetition of statements. Discourse repair is used in problematic situations, such as misunderstandings and communication breakdowns (Ellis 1994: 259) and is carried out through 'negotiation of meaning', which involves 'requests for clarification', 'requests for conformation', and 'self-and-other repetitions'.

\section{Corrective Feedback from an Interactionist Perspective}

The interactionist perspective refers to Michael Long's 'Interaction Hypothesis', which is closely connected to three language learning theories: 'Input Hypothesis' (Krashen 1982), 'Output Hypothesis' (Swain 1985) and 'Noticing Hypothesis' (Schmidt 1990; 1994).

\section{Input Hypothesis}

First and foremost, when speaking about Krashen's theories of language learning we need to distinguish between two concepts: 'learning' and 'acquisition'. While acquisition refers to a subconscious process, comparable to the way a child acquires a first language, learning refers to a conscious process, which goes hand in hand with metalinguistic knowledge and the conceptualisation of language (Krashen 1982: 10). 
Krashen's Input Hypothesis is only concerned with the process of implicit, subconscious language acquisition, not learning. ${ }^{1}$ The Input Hypothesis claims that language input on a level slightly higher than one's individual competence automatically leads to language acquisition. Krashen's formula ' $i+1$ ' represents the essence of his thoughts with ' $\mathrm{i}$ ' being the current status of language competence and ' +1 ' being the input slightly above this individual competence level (Krashen 1982: 2021). According to Krashen, comprehensible input in combination with a low affective filter, meaning relatively little negative feelings towards the process of language learning, constitute the ideal conditions for language acquisition. The modification of language input, such as simplifying input or providing contextual information, is conducted by the more competent interlocutor instead of being carried out through mutual interaction (Krashen and Terrell 1984: 19 and Mackey et al. 2012: 7). Krashen argues that corrective feedback does not facilitate language acquisition as there is a natural order of events in language learning similar to a child's acquisition of a first language (Krashen 1982: 12): 'Research in child language acquisition suggests quite strongly that teaching [...] does not facilitate acquisition. Error correction in particular does not seem to help' (Krashen and Terrell 1984: 27). On the contrary, Krashen states that explicit instruction is important in order to consciously learn language rules and metalinguistic skills: '[...] conscious language learning is thought to be helped a great deal by teaching: its goal is the learning of conscious rules and error correction is thought to help the learner [...]' (Krashen and Terrell 1983: 26), '[...] but it is not clear whether error correction has this impact in actual practice' (Krashen 1982: 11).

\section{Output Hypothesis}

During the 1980s Merrill Swain postulated the 'Comprehensible Output Hypothesis' as a counterpoint to Krashen's Input Hypothesis. Swain argued that input is indeed necessary but not enough for a language to be successfully learnt. Therefore her main claim is that successful language learning needs language production. Her theory was proven by observations of immersion classrooms in French Canada where children were exposed to a lot of language input but did not get many chances to practice their productive skills. These children all developed decent receptive competences, but their productive skills lagged behind. According to Swain, language production has three different functions during the process of language learning: '1) Noticing and triggering function 2) Hypothesis-testing function, 3) Metalinguistic (reflective) function' (Swain 2005: 471).

1 The status quo in second and foreign language learning attempting to dissolve the dichotomies of acquisition and learning, implicit and explicit learning, procedural and declarative knowledge. 
In this context 'noticing and triggering' refers to the recognition and identification of language gaps. Swain claims that 'the activity of producing the target language may prompt second language learners to recognise consciously some of their linguistic problems' (Swain 2005: 471). Therefore 'noticing and triggering' is also described as 'consciousness-raising' (Swain 1995: 128). Furthermore, output production does not only consolidate already existing knowledge, but has a knowledge creating function (Swain 2005: 471).

The second function of output production refers to the testing of language hypothesis. As a learner, we all have notions and ideas of how the language we are learning supposedly works. In order to prove these ideas we have to perform socalled 'trial runs' and actually produce language to see if we were right or wrong. These 'trial runs' are the main foundation for corrective interaction between learners and teachers, because without erroneous output there would not be a need for corrective interaction and output modification (Swain 2005: 476). In the revised version of Swains Output Hypothesis she introduced the notion of 'modified output'. Modified output refers to erroneous learner utterances that are immediately followed by a feedback move in which the learner himself or the teacher corrects (=modifies) the utterance. Through elicitation-e.g. Student: 'Once upon a time there lives a girl named Cinderella. Teacher: 'Once upon a time there...' (Sheen 2011: 4)-learners should be pushed to correct their own utterances. This immediate comparison of correct language use (positive evidence) and erroneous language use (negative evidence) is thought to facilitate language learning (Mackey 2012: 16).

The third function of output production is metalinguistic awareness, which has its origins in Vygotsky's sociocultural theory (Swain 2005: 478). Reflecting on 'language in use', either regarding our own utterances or utterances produced by other people, is important for language learning. Corrective feedback approaches based on Swain's Output Hypothesis act on the assumption that output prompting and output pushing feedback strategies are more facilitative for language learning than feedback that already includes the correct version and wording (Sheen 2011:25).

\section{Noticing Hypothesis}

One important aspect of the Output Hypothesis, 'noticing the gap', is linked to the Noticing Hypothesis by Schmidt $(1990 ; 1994)$. Schmidt's main argument is that implicit learning, meaning learning without awareness, is not possible. This means that there is a difference between input, meaning any type of target language input, and intake, meaning target language input that has been processed by the learner. For the act of processing awareness is a sine qua non. The learner has to be aware of the differences between the status quo of his or her interlanguage and the target 
language, otherwise lots of errors remain ignored. Further, Schmidt argues that corrective feedback facilitates the recognition and identification of language gaps:

The conversational modifications [...] (conformation checks, clarification requests, comprehension checks, recasts, and more explicit forms of feedback) play the role of not only providing input and facilitating output, but also of drawing learners' attention to problematic aspects of their interlanguages (Mackey 2012: 131).

\section{Interaction Hypothesis}

While Krashen claimed that language acquisition follows a predetermined natural order even in adulthood and therefore attached little importance to error correction, Long (1983) argued that instead of target language input in general, learners need a type of modified input that evolves out of reciprocal interaction, not only based on modification undertaken by one side. In Krashen's theory modification of input should always be carried out by the more competent speaker, i.e. the teacher in a classroom setting, while the Interaction Hypothesis focuses on the interactive nature of language learning and refers to it as 'negotiation of meaning'. Long (1996) defines 'negotiation of meaning' as a

process in which, in an effort to communicate, learners and competent speakers provide and interpret signals of their own and their interlocutor's perceived comprehension, thus provoking adjustments to linguistic form, conversational structure, message content or all three, until an acceptable level of understanding is achieved (Long 1996: 418).

During 'negotiation of meaning' the attention is drawn to linguistic form, structure, and content whereupon feedback plays an important role: 'By providing learners with information regarding their linguistic and communicative accomplishments or failures, this interactional feedback creates a favourable environment for $\mathrm{L}^{2}$ development' (Mackey 2012: 12). Traditionally seen 'negotiation of meaning' is carried out through the 'three C's'- 'Confirmation Checks', 'Clarification Requests' and 'Comprehension Checks'. 'Confirmation Checks' refer to check-backs to verify if the utterance has been correctly understood (e.g. 'Did you mean it like that?'), 'Clarification Requests' refer to check-backs to achieve a better, more precise understanding (e.g. 'What did you say and mean exactly?'), and 'Comprehension Checks' are check-backs on the part of the speaker in order to ascertain that the utterance has been understood (e.g. 'Did you understand what I said?') (Mackey 2012: 12).

2 L2: Second Language, meaning: any language learnt after the first language. The distinction between the terms 'Second Language' and 'Foreign Language' is often made with regard to the context of language learning. They draw upon the same theoretical framework, as both refer to languages learnt after L1 (first language). 
Interactional feedback as a result of communication problems, such as misunderstandings or even a communication breakdown, is called 'negotiation of meaning', while interactional feedback with a focus on linguistic form is referred to as 'negotiation of form' (Sheen 2011: 2). 'Negotiation of form' can be seen as the umbrella term for corrective feedback forms involving learner participation (output-prompting feedback).

\section{Corrective Feedback from a Sociocultural Perspective}

The origins of sociocultural theory are often associated with Leo Vygotsky, a Russian psychologist whose ideas haven been taken up and introduced to second language research by James P. Lantolf (Schoormann and Schlak 2012: 7). The main concept in sociocultural theory is 'mediation': 'human thinking is mediated by culturally organized and transmitted symbolic meaning' (Lantolf 2013: 57). For sociocultural theory any innerpsychic activity, e.g. language learning, is thought to be mediated. Similar to modifying our physical environment by using certain tools, we need non-physical symbolic means in order to regulate our social relations, whereas language is seen as the most important symbolic system of human civilisation (Lantolf 2000: 1 and Schoormann and Schlak 2012: 7).

Sociocultural theory defines 'learning' as 'a socially mediated activity that enables learners to achieve higher order mental functioning' (Sheen 2011: 29); we learn through social interaction. While interaction theory considers learning as an individual process, sociocultural theory puts the emphasis on social interaction in a broader context (Schoormann and Schlak 2012: 8). During the process of learning we undergo different levels of 'regulation': 'object regulation', 'other regulation', and 'self or auto regulation'. During the first phase one's learning behaviour is strongly influenced by objects. This can be observed with children, whose attention is easily attracted by objects, e.g. toys. An example for object regulation with regard to inner-psychic activities would be the use of a notepad for solving an arithmetical problem (Lantolf and Thorne 2007: 200). The second phase is marked by 'other regulation'. During the second phase of 'other regulation' one is not fully independent yet and still in need of 'a little help' from a more knowledgeable, more competent person. The last phase, 'self or auto-regulation' is determined by extensive autonomy. The learner is now able to carry out tasks independently, although even very advanced learners can fall back into object or other regulation temporarily, i.e. be in the need of 'a little help' once again (Lantolf and Thorne 2007: 204).

Besides mediation and regulation, the concept of 'internalisation' is another important term in sociocultural theory. Regulation is made possible through the process of internalisation. Internalisation refers to gradually obtaining control over a certain matter until the resources become internally available for the individual and there is 
ideally no need for externally provided mediation. In language acquisition the method of imitation is seen as the most effective means of internalisation, however internalisation does not mean repeating the same process over and over again, but rather describes a target-oriented adaption that develops over time (Lantolf and Thorne 2007: 207).

Corrective feedback within the framework of sociocultural theory is considered a form of mediation that facilitates regulation and internalisation (Sheen 2011: 29). While giving feedback, the most important factor to consider is the learner's 'zone of proximal development'. The 'zone of proximal development' by Vygotsky involves tasks a learner is not able to fulfil and solve on his own yet, but may achieve with 'a little help' from a more competent person. With regard to corrective feedback this means that a teacher should only give the amount of help and support that is absolutely necessary to successfully fulfil a task or solve a problem (Sheen 2011: 29). During a corrective feedback or mediation sequence teachers should start out with rather implicit cues, step by step moving on to more explicit, more concrete forms of feedback until the learner is able to phrase the desired utterance (Schoormann and Schlak 2012: 8). While learners during the initial stage might need quite explicit forms of feedback, a short interruption might be sufficient to initiate selfcorrection at a later point. Within the framework of sociocultural theory the learning success is not measured against the outcome or output (performance), but against the 'control over performance', meaning the degree of self-regulation, autonomy, and self-control (Lantolf 2012: 60). According to sociocultural theory it is likely that two learners are in fact committing the same (type of) error, but differ with regard to their developmental potential and levels of regulation (Schoormann and Schlak 2012: 9).

Criticism from sociocultural theory towards the interactionist perspective of language learning is aimed at the latter's overestimation of 'negotiation of meaning'. From an interactionist point of view 'clarification requests' are seen as an indicator for 'negotiation of meaning', but within the sociocultural framework they could also be seen as a 'request for repetition' or simply as social etiquette (Sheen 2012: 31). Generally speaking, sociocultural theory is mostly concerned with the dynamic process and not the product of learning; it speaks of 'negotiation of control over performance' (Lantolf and Poehner 2011: 29) instead of 'negotiation of meaning' and 'negotiation of form'.

In sum, sociocultural theory and interaction theory of language learning argue that language development is induced by interaction with more knowledgeable speakers. Interaction is necessary for triggering output, testing linguistic hypotheses, and noticing gaps. The process of noticing one's linguistic gaps and errors is, again, facilitated by corrective feedback. 


\section{Corrective Feedback in Classroom Practice}

In 1978 Hendrickson outlined five questions on corrective feedback in classroom practice that summarise the main aspects to keep in mind when discussing corrective feedback from a more practical point of view:

\section{Should Learner Errors Be Corrected?}

Several meta-studies, such as Russel and Spada (2006), Mackey and Goo (2007), Li (2010), and Lyster and Saito (2010) proved the effectiveness of corrective feedback. Whether errors should be corrected in classroom practice depends on different aspects such as classroom setting, error type, a learner's age, the attitude towards instruction and corrective feedback, and others. Interestingly teachers and learners tend to hold contradictory opinions on feedback practice in classroom settings. While teachers are afraid to interrupt their students and fear the negative influence of corrective feedback on learner motivation, learners often wish to be corrected more persistently. Moreover, students evaluate the competence of their teachers according to the promptness and quantity of corrective feedback. Attitudes towards corrective feedback are also connected to cultural background, learning experience, and language proficiency of the students (Lyster et al. 2014: 7).

\section{When Should Learner Errors Be Corrected?}

This question refers to the wider context of error correction on the one hand and to the timing of error correction on the other hand. Right context and right timing of error correction strongly depend on the content and aims of classroom instruction. If the main focus lies on 'accuracy' or grammar instruction, immediate 'on-line' feedback is widely advocated (Hendrickson 1978; Ellis 2009: 11; Sheen 2012: 40). In comparison, delayed 'off-line' feedback that pushes the learner to produce output is more suitable for a communicative language classroom setting in which it is not desirable to interrupt the speech flow (Ellis $2009: 11$ ).

\section{Which Learner Errors Should Be Corrected?}

Hendrickson (1978) argues that 'errors that impair communication significantly; errors that have highly stigmatising effects on the listener or reader; [and] errors that occur frequently in students' speech or writing' should be corrected (Hendrickson 1978: 392).

Corder (1967) differentiates between 'errors' and 'mistakes' and favours correcting 'real' errors only, as these are due to a lack of linguistic competence, while 
'mistakes' are incidental and do not need to be corrected. Another way of classifying errors is the differentiation between 'global errors' and 'local errors'. A global error impairs communication, while a local error is, for example, a morphosyntactic error that does not change the meaning of a structure. Especially in communicative settings the focus of corrective feedback should be on global errors. It has been observed that teachers often randomly choose which errors are corrected and which are ignored (Sheen 2011: 42). Sheen (2011) and Ellis (2009) therefore prefer a 'focused correction' where specific types of errors are being chosen in advance for correction.

\section{Who Should Correct Learner Errors?}

Corrective feedback can be carried out by the learner himself (self-correction), by class-mates (peer correction) or by the teacher (teacher correction). Hendrickson (1978: 195) argued that giving corrective feedback is an important duty of the language teacher, although in the long run learners should be aware of their errors and be able to correct themselves. The same thought was put in other words by Chaudron ten years later: 'It should be the goal of instruction to improve learners' ability to monitor their own target language speech' (Chaudron 1988: 150). Outputprompting feedback techniques are known to force students to produce language and therefore rely less on teacher-centred input in the long run, though self-correction is limited:

Learners can only self-correct if they possess the necessary linguistic knowledge [...] they can correct their 'mistakes', but not their 'errors'. Other (typically teacher) correction will be necessary to enable learners to identify forms that are not part of the interlanguage. [...] although output-prompting CF strategies signal, that there is some kind of problem with the learners' utterance, they do not make it clear, that the problem is a linguistic one (as opposed to just a communicative one) (Ellis 2009: 7).

Therefore, self-correction without the teacher's help is only suitable for correcting mistakes, but not for errors. Ellis (2009) prefers to 'first encourage self-correction and then, if that fails, [to] provide the correction' (Ellis 2009: 7; Doughty and Varela 1998).

Peer feedback is considered especially fruitful for correcting written texts (Hendrickson 1978; Chaudron 1988; Ferris 2003; Ellis 2009; Sheen 2012), though it is important to give the students instructions on feedback practice (Sheen 2012: 48). Whether the results of traditional, teacher-initiated corrective feedback research are also applicable on peer-feedback practice has not been researched in detail. 
The application of corrective feedback in classroom practice depends on 'linguistic targets, interactional contexts, students' age and proficiency and the classroom's communicative orientation and curricular objectives' (Lyster et al. 2013: 30). First, teachers should consider the error type. Mackey et al. (2000) discovered that implicit feedback on morphosyntactic errors is less salient than with regard to lexical or phonological errors. The 'counterbalance hypothesis' suggests that feedback strategies should counterbalance the instructional setting in order to put the learners' focus and attention on the error (shift-of-attention). This would mean that reformulations like recasts are especially suitable for form-focused classrooms and outputprompting, form-focused feedback methods for meaning-oriented classrooms.

In search for a systematic categorisation, Lyster and Ranta (1997) investigated corrective feedback strategies in an immersion classroom context. They put together a corrective feedback typology consisting of six different types of feedback, grouped into 'reformulations' and 'prompts'. Based on these results Ellis and Sheen (2006) developed a slightly modified typology which is discussed later on in this section.

\section{Corrective Feedback Typologies}

\section{Reformulations}

Reformulations are corrective feedback types that do not involve active participation by the learner as the correct formulation is given by the teacher.

For Lyster and Ranta (1997) 'explicit correction' and 'recasts' are considered reformulations:

- 'Explicit correction': refers to a clear and obvious correction of an error. Explicit corrections usually include the correct reformulation of the utterance as well as an explicit indication that there was something wrong. Explicitness can be expressed through verbal indications, gestures or facial expressions.

- 'Recast': refers to the reformulation of an erroneous utterance without a clear indication that something was wrong, therefore, recasts count as prototype for implicit feedback. The observation of immersion classrooms in Canada showed that recasts were by far the most popular feedback type in these classroom settings. 


\section{Prompts}

- 'Clarification Request': refers to check-backs, such as asking the learner for clarifying an erroneous or unclear utterance. For example: 'Pardon?', 'What did you mean?' Clarification requests count as output-prompting feedback type, because the correct form is not given by the teacher. Along the continuum of explicitness and implicitness, clarification requests are considered to be rather implicit.

- 'Metalinguistic Feedback': refers to comments and information on the erroneous part of an utterance in order to 'push' the learner towards the correct answer. For example: 'What tone is that?' 'I heard a second tone', 'Pay attention to the tones'. Along the continuum of explicitness and implicitness it is rather explicit.

- Elicitation: refers to different methods aiming at extracting the correct answer. Usually in this case the teacher will repeat the correct part of the utterance and stop before reaching the erroneous part. For example: Student: Wo3 shi4 ao di li4ren2 (I am Austrian* - wrong pronunciation of 'Aodili' (Austrian). Teacher: Ni2/3(3) shi4 (...) zai4 lai2 yi2 bian4 (You are (...) - repeat one more time!)

- Repetition: refers to the repetition of an erroneous utterance, often exaggerating problematic parts or adding a rising intonation in order to make the correction more salient.

Sheen and Ellis's (2006) corrective feedback typology is based on Lyster and Ranta's (1997) category system. The main differences are the differentiation between didactic recasts and conversational recasts as well as the adoption of a new category: 'explicit correction with metalinguistic explanation'. Recasts were traditionally seen as prototypes for implicit feedback (cf. Lyster and Ranta 1997), however, 'didactic recasts' referring to reformulations with a specific didactic focus can be quite explicit:

First, the teacher repeated the student's erroneous utterance, stressing the deviant parts. Second, the teacher reformulated the utterance, again stressing the corrected items. This procedure was specifically designed to make the corrected items salient to the learners. In so doing, it arguably made the corrective nature of recasts quite explicit (Ellis and Sheen 2006: 583).

The following illustration (based on Lyster et al. 2013) aims at portraying the continuum between implicit and explicit: 


\section{Prompts}

Clarification Request -- Repetition -- Paralinguistic Signal -- Elicitation -- Metalinguistic Cues

Implicit Explicit

Conversational Recast -- Didactic Recast -- Explicit Correction -- Explicit Correction with Metalinguistic Cue

\section{Reformulations}

\section{Pronunciation Instruction in CFL Teaching}

In second and foreign language teaching ${ }^{3}$ a distinction is made between two methods of pronunciation teaching: The intuitive-imitative method and the analyticallinguistic method (Celce-Murcia et al. 2010: 2). The intuitive-imitative method is based upon naturalistic approaches to language teaching and requires the learner's ability to identify and mimic presented sounds without explicit instruction. In the late nineteenth century, along with the development of the International Phonetic Alphabet, a reform movement in the field of second language teaching was initiated, leading to the establishment of phonetics as a scientific discipline and subsequently to the rise of the analytic-linguistic approach in second language pronunciation teaching (Celce-Murcia et al. 2010: 3). In the 1940s and 1950s, during the prime of audio-lingual methods, phonetics gained significance in second language teaching. Pronunciation instruction within to the analytical-linguistic approach was now carried out more explicitly, using the International Phonetic Alphabet, articular descriptions, charts of the vocal organs and contrastive information to complement the intuitive-imitative approach. Along with the rise of audio-lingual methods the application of language laboratories for pronunciation instruction increased. Language laboratories, equipped with student cabins, teacher console and audio system (nowadays video system) was used as a specific environment for pronunciation instruction, in which the language teacher was able to present sound samples. The audio system contained an interphone system, which made it possible for the language teacher to give instructions and supervise activities at all times (Stack 1966: 1). Traditionally, language laboratory instruction consisted of pattern exercises, the core of audio-lingual language teaching (Kummer and Willeke 1970: 23). While these methods put their focus on precision and obtaining native-like pronunciation, communicative language teaching starting from the 1980s brought the functionality of language to the foreground. The main goal of language teaching or, in a narrower sense, pronunciation teaching now was not obtaining 'perfect', native-like pronun-

3 Second and foreign language are used interchangeably. 
ciation anymore, but to be able to communicate successfully (Celce-Murcia etl a. 2010: 9).

In regard to pronunciation instruction for Chinese as a foreign language, three main approaches exist: 1) Traditional phonemic instruction (yǔsù jiàoxué 语素教学), 2) Speech-flow instruction (yǔliú jiàoxué 语流教学), and 3) Syllable instruction (yiñjié jiàoxué 音节教学) (Gù and Wú 2005).

The starting point of the traditional phonemic instruction is the phoneme, which is defined as 'the smallest contrastive linguistic unit which may bring about a change of meaning' (Gimson 2008: 41). In the case of CFL, teaching phonemes consisting of consonants only means teaching sounds without tones, as tones are carried by vowels. Starting from there, larger units like words are approached. The main points of criticism on phonemic instruction therefore is that tones are partially excluded, leading to a lack of functionality. With the rise of communicative language teaching in the 1980 s, the so-called speech-flow instruction gained popularity. Pronunciation instruction was now integrated in communication exercises, training whole phrases and sentences instead of isolated phonemes. Supporters of the speech-flow approach argue that this method helps with avoiding the typical 'foreign accent' (yáng qiāng yáng diào 洋腔洋调) which develops because of a lack of combining syllable tones with stress and intonation (Lŭ 2005). The disadvantage lies in the absence of a systematic understanding of phonetic construction of syllables, which is especially important for transliteration in Hanyu Pinyin (Gù and Wú 2005). More recently, the syllable approach has become the prevailing method of pronunciation teaching in Chinese as a foreign language (Gù and Wú 2005 and Zhōu Xiăobīng 2009: 61).

The foundation of this teaching method is the syllable, which acts as a starting point for addressing smaller language units - for example, consonants, vowels - but also larger language units - for example, words, phrases, and sentences. The great advantage of syllable instruction lies in the systematic instruction of pronunciation, whilst still following the principle of functionality, as meaningful words, instead of just random sounds, are taught from the beginning. One of the main problems is that students often acquire the pronunciation of a new vocabulary by memorising the sound complex, but without the syllable tone. The separate instruction of sounds and tones leads to the notion of sounds and tones being individual phenomena (Hunold 2004). The syllable approach includes the three parts of the Chinese syllable: Onsetoffset-tone. ${ }^{4}$

4 Generally a Chinese syllable consists of 'Onset-Offset-Tone'. However, there are also a number of 'zeroonset' syllables, for example 'àn', which does not have a consonant as syllable onset. A Chinese syllable does not need a consonant, however it always needs a vowel, because the vowel 'carries' the tone. 
Tone

Onset - Offset

m - ă

(mă 马- Horse)

This is therefore seen as the most reasonable and 'natural' teaching method with regard to Chinese being a tonal language (Gù and Wú 2005).

Zhōu Xiăobīng (2009: 61) argues for the systematic instruction of sounds and tones (syllable method) but switching to a more communicative method after the initial state in order to put more emphasis on tonal variations and intonation.

Mimicking and imitating are still widely used in Chinese language classrooms, although this presupposes that the language learner has the ability to differentiate between certain sounds and tones. But also more explicit forms of instruction, such as exaggerating or comparing sounds are very common (Zhōu Xiăobīng 2009). Using not only verbal, but also visual exaggeration helps to show the difference between similar sounds more clearly. For example, to point out the difference between the syllables /an/ and /ang/ the teacher draws the mouth angle wide apart while pronouncing 'an', while opening up the mouth and shaping the lips like a big circle when pronouncing the syllable 'ang'. These methods are often supported by illustrations of the vocal organs, as well as explicit descriptions of their movement (Zhōu Xiăobīng 2009). A number of teaching manuals suggest contrastive analyses between Chinese and the learner's first language and native language for the instruction of difficult, problematic sounds and even claim that without sufficient knowledge of the learner's first language and native language efficient instruction is not possible (Zhōu Jiàn 2009: 8; Zhōu Xiăobīng 2009: 58; Lǔ 2010). Research shows that the acquisition of tones is a major challenge for most CFL learners, especially during the initial stage, although not only learners with non-tonal language background, but surprisingly also learners with tonal languages like Cantonese or Thai as L1 (first language) struggle to identify, imitate and pronounce Mandarin tones correctly. Hao (2012) showed in a case study that Cantonese speaking natives struggled to identify Mandarin tones. Hao argues that this can be traced back to the overlapping of Cantonese and Mandarin tones. In addition to more conventional methods of tone instruction by using illustrations and gradually combining tones with sentence intonation and word stress, a number of alternative teaching methods like tone instruction through music or computer assisted pronunciation training (CAPT) have been proposed over the decades. Jin and Lang (2005) suggest 'emotionally-charged' phrases as a starting point for the instruction of tones and sentence melody, while Chao (1948), Woo (1976), and Lin (1985) demonstrate the movement of Chinese syllable tones according to musical intervals. The notation of whole sentences and dialogues within the established Western notation system of five 
horizontal lines and four spaces was proposed by De Francis (1963) but has not been widely used due to its impracticability. ${ }^{5}$ The idea of tone instruction through music has recently been taken up by Zhang (2011) and suggests the usage of music instruments like the violin or the piano to demonstrate Chinese tones.

Computer Assisted Pronunciation Training (CAPT) is regarded as a very fruitful and future-oriented field in pronunciation instruction. Nevertheless, TeLL me moreChinese is the only computer software with speech recognition technology for syllable tones and intonation available to date. It detects pronunciation errors based on the 'Spoken Error Tracking System' and contains 3D-Animation for phonetic input. In theory this kind of programmes is very promising, even though in 'real life' a number of difficulties, such as the correct evaluation of output, error detection, and error diagnosis, arise (Zhang 2006: 130). Some issues of greater concern are the lack of meaningful feedback and the support of feedback interpretation.

Against the background of Chinese being a tone language and its pronunciation posing a challenge for most CFL learners, researchers and language teaching professionals have been broaching the issue of CFL pronunciation instruction in general. Yet, there is a scarcity in research concerning the systematic investigation of corrective feedback on CFL learners' pronunciation.

\section{Case Study}

\section{Research Aim}

Most corrective feedback studies deal with the correction of grammatical errors within communicative-oriented language instruction and focus on English as a second language (Lyster et al. 2013: 21). Research on corrective feedback targeted at pronunciation errors remains relatively sparse. Lyster et al. (2013: 25) mention that the influence of corrective feedback on speech rate, intonation, and rhythm are as yet to be investigated. The aim of this case study is to examine teacher-centred ${ }^{6}$ corrective feedback on CFL learners' pronunciation errors. For that matter, language laboratories courses at the University of Vienna have been chosen as the observation field, because these classes focus on pronunciation instruction. The study conducted during Spring term in 2013 aimed at answering the following research questions:

- Which corrective feedback types are applied when correcting CFL learners' pronunciation errors?

5 John DeFrancis' textbooks 'Beginning Chinese' and 'Intermediate Chinese' were used as teaching material at the Department of Sinology (University of Vienna) in the early years of its existence.

6 Meaning corrective feedback given by the teachers as opposed to peer feedback. 
- Which strategies and methods are used for that matter?

- To what extent are the existing corrective feedback types of Lyster and Ranta (1997), Sheen and Ellis (2006) and Sheen (2011) applicable to the correction of CFL learners' pronunciation errors?

\section{Research Setting}

Two sessions of two different language laboratory courses (Sprachlaborübungen) at the level of second semester within the B.A. curriculum of Sinology have been observed and documented with audio- and video-recording devices. Both students and teachers were informed about the purpose of the study, although the exact research questions were not revealed. In the following the observed classes are named 'language laboratory $A$ ' and 'language laboratory B'. According to the description in the course directory the aims of language laboratory A were reading aloud precisely and clearly, as well as speaking freely (introducing oneself, describing daily life [activities]), using listening, reading along and imitating as teaching methods. Language laboratory B intended to focus on precise pronunciation in order to master the Chinese language. Pronunciation refers to the Chinese phonetic alphabet including consonants, vowels, tones, word stress, and sentence stress. Even though language laboratory A defined 'speaking freely' as one goal, it has to be pointed out that language lab courses within the Sinology B.A. curriculum are considered more form-focused, while conversation courses are supposed to focus on meaning. The language lab courses in general use Hànyǔ jiàochéng, dì yī cè: xià 汉 语教程, 第一册: 下 (Chinese-course, First Volume: Second Part) (Yáng 2007) as their main teaching material.

\section{Research Environment}

\section{Language Laboratories (University of Vienna)}

Built in 1999, the two new language laboratories of the University of Vienna are equipped with 20 student cabins, including computers and an independent audio and video network. A control desk connected to an interphone system allows the teacher to distribute audio-material and be in contact with the students at all times (Hönigsperger and Potuzak 2001). Language laboratories are often associated with the audio-lingual method, which is based on the assumption that language learning means creating a set of new 'habits'. Therefore learning within the audio-lingual method usually involved repeatedly practicing oral pattern drills. Although the first language laboratories were developed against the background of audio-lingual 
language teaching, today's facilities, such as the language laboratory of the University of Vienna, are mostly used for their spatial infrastructure, applying different, more up-to-date methods.

\section{Participants}

\section{Teachers}

The teachers of both course A and course B are originally from mainland China with Mandarin Chinese being their language of education and 'near-native' German proficiency. Both teachers had attended academic teacher education programs for Chinese, teacher A completed her studies in China and teacher B studied in Germany and Austria. Both teachers already had several years of teaching experience with regard to Chinese as a foreign language (different Chinese language courses at the University of Vienna, adult education institutions, etc.). At the time of the study (Spring term 2013), B was conducting a language laboratory course for the first time, while teacher A had already taught this type of course for three semesters. The language of instruction was mostly Chinese, only in rare cases German was used.

\section{Students}

The participating students were all in their second semester of the B.A. programme 'Sinology' at the University of Vienna (except for a few exchange students) and therefore had a basic knowledge of Hànyù jiàochéng, dì yī cè: xià (Yáng 2007)—the main teaching material for first semester students of the B.A. programme 'Sinology'—as well as parts of Hànyǔ tīnglì jiàochéng 汉语听力教程 (Chinese Listening Course) - a text book for listening comprehension (Yáng 2000). After having completed the first semester the students should be familiar with the sound inventory and tone system of Mandarin Chinese.

\section{Methodology}

\section{Data Collection}

The observed language lab sessions were documented with audio and video recording devices. Because the focus of this case study is on teacher feedback and not on the actual errors made by the students, the audio device was placed as close as possible to the teacher. 180 minutes of data material have been documented altogether. All recordings were conducted by the author. 


\section{Sequence Selection and Transcription}

As a first step all sequences including corrective feedback moves were identified. According to Lyster and Ranta (1997: 44) a corrective feedback move is always preceded by an erroneous utterance, this could be a grammatical, lexical, semantic or phonological error. For this case study only corrective feedback on phonological errors was chosen. Therefore, a transcription sequence starts with a phonological error which can be ignored or taken up by the teacher. Due to the above named research questions only errors that were followed up by a corrective feedback move were relevant for the data analysis. Errors that had been ignored were therefore not transcribed. The (data) transcription was carried out with the computer programme 'EXMARaLDA' (Extensible Markup Language for Discourse Annotation). This transcription programme was chosen in order to be able to show overlapping talk. ${ }^{7}$

\section{Transcription Rules}

Utterances in Mandarin were transcribed in Hanyu Pinyin with numbers instead of diacritics for tones.

e.g. 'wo3 er4shi2yi1 sui4' (我二十一岁 - I am twenty-one years old)

In the transcription a large number of syllables have two different numbers for tones, one right after the syllable and one put in brackets. This is due to the fact that the pronunciation of tones may vary according to the syllable that follows. The most frequent tone variation is the change of third to half-third or second tone, if followed by another third tone. In those cases the original lexical tone was put right after the syllable, and the pronounced tone was put in brackets.

\section{e.g. 'wo2(3) shu2/3(3) she2 de' (我属蛇的 - I am a snake [in Chinese astrology])}

The transcription of erroneous tones was a challenge, because there is no standard transcription method. During the transcription process, erroneous tones were identified as precisely as possible and indicated with corresponding numbers for the actually produced tone. If the tone could not be identified at all it was marked with a ' '. Word stress was indicated with capital letters:

$$
\text { e.g. 'wo2(3) shu2(3) gou2/3(3) DE1[...]' (我属狗的 - I am a dog [in Chinese astrology]) }
$$

The reduction of speech rate was indicated through doubling the gaps.

$$
\text { e.g. 'w o2(3) s h u2(3) m a3 d e' (我属马的 - I am a horse [in Chinese astrology]) }
$$

\footnotetext{
7 Both or more parties speaking at the same time, when engaging in a conversation.
} 
Short breaks were indicated with a point put in brackets (.), longer breaks with two points (..) and so on.

The transcription was primarily aimed at the dynamics of spoken language. Upper and lower case in Hanyu Pinyin were therefore set apart if necessary, i.e. in cases where capital letters had to be used to indicate word stress.

\section{Data Analysis}

The data analysis was carried out by applying the method of qualitative analysis developed by Mayring, which is a theory-based analysis of fixed communication. The meaning of statements can only be analysed with regard to a predefined research question (Mayring 2008: 12). During the first phase a deductive content analysis was conducted. To this end the existing corrective feedback typology by Lyster and Ranta (1997) was applied to the transcribed data in order to identify which types of feedback were used and/or to what extent this existing typology has to be modified to fit the context of CFL pronunciation instruction. During the second phase, using inductive analysis new categories were identified and the existing typology further differentiated.

\section{Coding}

The identification of corrective feedback referred to 'any feedback that provides learners with evidence that something they have said [...] is linguistically incorrect' (Sheen 2011: 2). The identification of explicit feedback was more challenging due to the complexity of the definition and operationalisation of the term 'explicitness', as mentioned by Lyster et al. (2013: 3):

[...] explicitness is a difficult variable to hold constant across classroom studies because learner perceptions of salience and linguistic marking are affected not only by learner variables such as age and metalinguistic knowledge but also by contextual variables such as the instructional context and its communicative orientation.

Lyster et al. (2013: 4) define explicitness as 'clear indication of an error', Sheen (2011: 3) identifies the appearance of explicitness if '[the teacher] clearly signals to the learner that he/she has made an error', and Lyster and Ranta (1997: 46) define corrective feedback as explicit if it '[...] clearly indicates that what the student had said was wrong'. This indication is usually made verbally, for example by saying 'Oh you mean', 'You should say' (Sheen 2011: 3), or by comparing erroneous utterances to correct utterances, 'It's X, not Y'. However, explicitness may also be expressed non-verbally by using paralinguistic signals, though this has yet to be investigated in more detail (Lyster et al. 2012: 3). Ladd (2008: 35-36) refers to 
paralanguage as 'modifications of the way in which phonological categories are realised' and mentions 'loudness, voice quality und pitch range' in particular.

\section{Results}

The categories 'recasts', 'explicit correction', 'clarification requests', and 'elicitation' could be identified within the data material. A total of 158 feedback moves consisted of 119 explicit corrections, 34 recasts, 4 elicitations and 1 clarification request.

These results show that 'explicit correction' clearly outnumbers other corrective feedback methods. While Lyster and Ranta (1997) only propose a single category for explicit correction, Ellis and Sheen (2006) add the category 'explicit correction with metalinguistic explanation'. In order to obtain even more detailed results the category of explicit correction was further differentiated, using the method of inductive analysis. The term 'explicitness' defined as 'clear indication of an error' (Lyster et al. 2013: 4) was concretised through three modes of implementation.

\section{Explicit Correction}

\section{Explicit Correction using Explication (simple / extended) \\ 2. Explicit Correction using Comparison \\ 3. Explicit Correction using Reduction}

Explicitness enhanced by:
a. Paralinguistic cues
b. Visualisations
c. Additional verbalisation

\subsection{Explicit Correction Using Simple Explication}

During corrective feedback using simple explications, the teacher gives rather short explanatory notes regarding the preceding error:

'wo2(3)', ,wo2(3)' - di4 er4sheng1, ,shu3' - di4 san1sheng

I, I - second tone, , count as' [Chinese zodiac sign] - third tone 


\subsection{Explicit Correction Using Extended Explication}

During corrective feedback using extended explications, the teacher gives detailed information, for example on phonological rules. The distinction between 'simple explications' and 'extended explications' is not only made according to the length of a feedback sequence, but also with regard to how detailed the explanation is. Therefore certain key words, such as 'yin1wei4 [...], dan4shi4 [...]'suo2yi3' (because [...], but $[\ldots]$, for that reason $[\ldots])$ were identified as indicators:

Two times second tone - second, second. 'I', because it is originally a third tone, but here is also a third tone and here is a third tone, for that reason 'wo2(3) shu2(3) ma3 de'. ['I am a horse' [Chinese zodiac sign].

\section{Explicit Correction Using Comparison}

The immediate comparison between correct and erroneous utterances has up to now not been defined as an independent category, although Sheen (2011:3) mentions this type of feedback as example of explicit correction. The comparison between positive and negative evidence might help those learners who are yet not capable of distinguishing certain sounds or tones.

For example: 'bu2 shi4 'jü2/3(3)xing1', 'jü2/3(3)xing2' [It's not 'holding' [second syllable pronounced with first, instead of second tone, 'holding' [second syllable pronounced correctly, using second tone]]

\section{Explicit Correction Using Reduction}

The method of reduction refers to a spontaneous error analysis aiming at the isolation of a specific problem. This could be the problematic pronunciation of a specific sound or tone.

The following example shows the isolation of the vowel /i/. The mispronunciation of $/ \mathrm{i} /$ is often a result of the different realisation of $/ \mathrm{i} /$ after palatal sounds and retroflex-/dental-sounds, respectively.

['not sheng1rii4 ${ }^{8}$ sheng1ri4'], zhi, chi, shi, ri

Isolation of pronunciation problem connected to the relation of certain syllable onsets and offsets

The second example shows the isolation of a tonal error:

8 'ii' as in 'easy' (IPA: [i], Hanyu Pinyin [yi]). Student mispronounced the syllable offset. 
yes second tone is 'e e e e e 2 " [demonstrates rising intonation], fourth tone 'e e e e e 4' [demonstrates falling intonation]

'Explicitness' was further enhanced through three different modes:

\section{a. Paralinguistic Cues}

\section{Exaggeration and Stress}

In order to highlight the contrast between positive and negative evidence, exaggerations and syllable stress are applied.

$$
\begin{aligned}
& \text { bu2shi4 'ni2/3(3) DE4 sheng1ri4', ni2/3(3) de sheng1ri4 } \\
& \text { not, 'your birthday',.... [error exaggerated] } \\
& \text { bu2 shi4 'er1shi2yi'. 'ER4shi2yi1 } \\
& \text { not, twenty-one, TWENty one,... [correct tone exaggerated] }
\end{aligned}
$$

\section{Reduction of Speech Rate}

Another method of making corrections clearer is by reducing one's speech rate. Often the teacher is using normal speech rate, followed up by repeating the same utterance with a lowered speech rate.

$$
\begin{aligned}
& \text { wo2(3) shu2(3) ma3 de - w o2(3) s h u2(3) } \mathrm{m} \mathrm{a} 3 \mathrm{~d} \mathrm{e} \\
& \text { I am a horse [in Chinese astrology] - (repeated at lower speech rate) }
\end{aligned}
$$

\section{b. Visualisation}

Corrective feedback regarding tones and intonation is often supported by gestures. A straight movement of the hand from left to right means first tone, a diagonal movement from left (bottom) to right (top) means second tone, a falling movement followed up by a rising movement means third tone and a falling movement from left (top) to right (down) means fourth tone.

\section{c. Additional Verbalisation}

Additional verbal notes, such as bú shì 不是 ('not'), q̌̌ng zhùyì 请注意 ('attention please') highlight the explicitness of corrective feedback even further and direct the

9 'e' as in 'duh' (IPA [ə], Hanyu Pinyin [e]), the gaps between 'e' demonstrate the elongation of the syllable. 
focus of the students to the relevant areas. With the exception of corrective feedback on pinyin dictations, which is an established method in CFL teaching in order to train receptive as well as productive skills, relatively little output-prompting feedback has been applied. Although the productive part of pinyin dictations are written, feedback was given orally in class.

\section{Summary and Discussion of Findings}

The results of the case study showed that CFL learners' pronunciation errors tend to be corrected in a very explicit manner. While earlier corrective feedback typologies developed for the analysis of Western language teaching (Lyster and Ranta 1997, Ellis and Sheen 2006) offer only one or two categories for explicit correction that are not output-prompting this case study was able to identify three methods of explicit correction leading to a further differentiation of the category 'explicit correction' into: 'explicit correction using explication' (simple and extended), 'explicit correction using reduction', and 'explicit correction using comparison'. As shown above, explicit correction using explication refers to adding information during corrective feedback. This method may be used to give the learner quick reminders (simple explication), if a mistake happened accidentally, or to give detailed, in-depth explications on phonological rules (extended explication) if needed. The study further showed that explicit correction could also be carried out the opposite way, i.e. by way of reduction. Reduction refers to isolating the main error or source of errors. Regarding CFL teaching this could be certain tones, intonations or syllable onsets and offset. Lastly, as a third method the study identified explicit correction using comparison of positive and negative evidence. This type of feedback especially addresses the needs of learners who are not yet able to distinguish between certain sounds and tones.

As mentioned above, the relevant literature defines explicitness as a 'clear indication of an error' (Lyster et al. 2013: 4), but lacks more detailed explanations on this issue. This case study was able to show that visualisations, paralinguistic cues, and additional verbalisations are used in order to enhance explicitness of corrective feedback sequences. Visualisations like gestures of tones and intonation and the use of white boards and black boards for illustrations are used to make corrections more understandable. Prior research showed that 80 to 90 per cent of all messages that are transmitted to our brain are visual cues, whilst only 11 per cent are acoustic signals. For teaching purposes this means that the instruction should appeal to different human senses, even in the case of pronunciation training (Zhōu 2009: 59). 'Exaggeration and stress' and 'reduction of speech rate' were identified as types of paralinguistic cues. Nevertheless, their application can be problematic in the context of CFL pronunciation instruction, as reduced speech rate and exaggerated stress may 
lead to unnatural speech rhythm and modified tones. For example the third tone in Mandarin Chinese is rarely pronounced as a full third tone when speaking at a normal speech rate, ${ }^{10}$ so this difficulty should be kept in mind during pronunciation instruction and feedback.

A possible explanation for the results presented above needs to take the specific classroom context and classroom content into consideration. Specifically targeted at pronunciation, the language laboratory courses clearly do not have a communicative focus as the priority is given to phonetic accuracy. Explicit feedback methods have been criticised for interrupting the natural flow of conversation and supplying the learner with the correct, target-like form, hence, not pushing modified output enough. The specific circumstances of a non-communicative, form-focused classroom context defuse these arguments and might explain the extensive use of explicit corrective feedback in this case.

\section{Pedagogical Implications for the CFL Classroom}

According to Mackey et al. (2000: 493) learners take better note of the correction of phonetic and lexical errors than of the correction of morphosyntactic errors, because phonetic and lexical errors have a larger impact on communication than grammatical errors. For learners of Mandarin Chinese, pronunciation is of great importance and highly challenging as their ability to communicate depends on the correct production of sounds and tones. This means that CFL learners are, in general, likely to be aware of pronunciation errors and even more in a language course specifically aimed at pronunciation instruction. However, the mere identification of an error followed by corrective feedback does not mean that differences between 'right' and 'wrong' are even noticed. Therefore, with respect to Schmidts 'Noticing-Hypothesis' (1990; 1994) and the particular challenging circumstances of Chinese pronunciation instruction, explicit feedback methods, even in highly form-focused settings, such as language laboratories, are very likely to be fruitful.

From the point of view of sociocultural theory the main goal of second and foreign language instruction is for the learner to achieve a high level of 'control over performance', which means that the individual language proficiency has to be considered for choosing the right 'fit' of feedback methods along the continuum of explicitness and implicitness. In other words, the teacher or tutor should only give as much assistance as the learner needs in order to fulfil a task successfully. After an initial instructive phase with rather explicit corrective feedback this means a transition to a more learner-centred approach and the avoidance of automatic explicit

10 The full third tone with its falling and rising part is only realised in regular speech if there is no other syllable following. For example: 好 - hăo (alright, okay, good) as an answer to a prior question or when stressing the syllable. 
feedback. In classroom practice students should be given an appropriate amount of time for self-correction with more or less guidance from the teacher, according to the learner's individual level. With the teacher transitioning from the instructor into the role of the facilitator and the encouragement of self-correction, more and more responsibility, in the sense of sociocultural learning theory, is given to the learner. This flexible corrective feedback approach is a lot more time consuming than applying the same feedback methods on every student / in every context and therefore works best in teaching situations without rigorous time constraints.

Lastly, affective factors and individual attitudes towards pronunciation instruction and corrective feedback should be taken into consideration. ${ }^{11}$ Despite this paper's focus on error correction, the author would like to point to the importance of complimenting students for their achievements - not least in view of the fact that pronunciation is 'the aspect of foreign language learning most sensitive to the impact of human emotions' (Jedynak 2013: 60). Choosing the right way of giving feedback requires experience and sensitiveness, and undoubtedly cannot be reduced to a simple answer or 'recipe'.

11 Further reading: Jedynak 2013 and Waniek-Klimczak et al. 2013. 


\section{REFERENCES}

Celce-Murcia, Marianne, Donna M. Brinton, and Janet M. Goodwin. Teaching Pronunciation: A Course Book and Reference Guide. New York: Cambridge University Press, 2010

Chaudron, Craig. Second Language Classrooms: Research on Teaching and Learning. Cambridge: Cambridge University Press, 1988

Chao, Yuan-Ren. Mandarin Primer. Cambridge: Harvard University Press, 1948

Corder, Pit. "The Significance of Learners' Errors." In International Review of Applied Linguistics, 5, 1967, pp. 161-169

Corder, Pit. Error Analysis and Interlanguage. Oxford: Oxford University Press, 1981

De Francis, John. Beginning Chinese. Revised Edition. New Haven: Yale Language Series, 1963

Doughty, Catherine and Elizabeth Varela. "Communicative Focus on Form." In Focus on Form in Classroom Second Language Acquisition, edited by Catherine Doughty and Jessica Williams. Cambridge: Cambridge University Press, 1998, pp. 114-139

Ellis, Rod. The Study of Second Language Acquisition. Oxford: Oxford University Press, 1994

Ellis, Rod and Younghee Sheen. "Re-examining the Role of Recasts in Second Language Acquisition." In Studies in Second Language Acquisition, 28/4, 2006, pp. 575-600

Ferguson, Charles A. "Baby Talk as a Simplified Register." In Talking to Children: Language Input and Acquisition, edited by Catherine E. Snow and Charles A. Ferguson. Cambridge: Cambridge University Press, 1977, pp. 209-235

Ferguson, Charles A. "Talking to Children: A Search for Universals." In First Language Acquisition: The Essential Readings, edited by Barbara Lust and Claire Foley. Malden: Blackwell Publishing, 2004, pp. 176-189

Gimson, Alfred C. Gimson's Pronunciation of English, edited by Alan Cruttenden, London: Hodder Arnold Publication, 2008

Gù, Zhēng 顾笔 and Wú Zhōngwěi 吴中伟. “Liúxuéshēng rùmén jiēduàn yǔyīn jiàoxué yánjiū" 留学生入门阶段语音教学研究 [Research on Teaching Phonetics to Overseas Students during the Initial Stage]. In Yúnnán shïfàn dàxué xuébào 云南师范大学学报 [Journal of Yúnnán Normal University], 3/2, 2005

Hao, Yen-Chen. "Second Language Acquisition of Mandarin Chinese Tones by Tonal and Nontonal Language Speakers.” In Journal of Phonetics, 40/2, 2012, pp. 269-279

Hendrickson, James. "Error Correction in Foreign Language Teaching: Recent Research and Practice.” In The Modern Language Journal, 62/8, 1978, pp. 387-398

Hönigsperger, Helmuth and Vera Potuzak. "Modernes Sprachlabor im Alten AKH.” 2001, Comment, 1/01, Zentraler Informatik Dienst website, http://comment.univie.ac.at/01-1/10, accessed June 2014

Hunold, Cordula. "Probleme der chinesischen Phonetik für deutsche Chinesischlernende". In CHUN (Chinesischunterricht), 19, 2004, pp. 33-48

Jedynak, Małgorzata. "Affecticity in Learning L2 Phonology/Phonetics - The Role of Self-concept in Successful Acquisition of English Pronunciation." In The Affective Dimension in Second Language Acquisition, edited by Danuta Gabryś-Barker and Joanna Bielska. Bristol: Multilingual Matters, 2013, pp. 60 - 73

Jin, Meiling und Heribert Lang. "Emotionsgeladene Kurzsätze als Basismodell chinesischer Ausspracheübungen.” In CHUN (Chinesischunterricht), 20, 2005, pp. 67-82

Krashen, Stephen. Principles and Practices in Second Language Acquisition. Oxford: Pergamon Press, 1982

Krashen, Stephen and Tracy Terrell. The Natural Approach. Oxford: Pergamon Press, 1984

Krashen, Stephen. The Input Hypothesis: Issues and Implications. London: Longman, 1985 
Kummer, Manfred and Ottomar Willeke. Arbeitsformen und Abläufe im Sprachlabor. Heidelberg: Groos Verlag, 1970

Ladd, Robert D. Intonational Phonology. Cambridge: Cambridge University Press, 2008

Lantolf, James P. "Sociocultural Theory: A Dialectical Approach to L2 Research." In The Routledge Handbook of Second Language Acquisition, edited by Susan M. Gass and Alison Mackey. New York: Routledge, 2012, pp. 57-73

Lantolf, James P, ed. "Introducing Sociocultural Theory." In Sociocultural Theory and Second Language Learning. Oxford: Oxford University Press, 2000

Lantolf, James P. and Stephen L. Thorne. "Sociocultural Theory and Second Language Learning." In Theories in Second Language Acquisition: An Introduction, edited by Bill VanPatten and Jessica Williams. New Jersey: Lawrence Erlbaum Associates, 2007, pp. 197-221

Lantolf, James P. and Matthew E. Poehner. "Dynamic Assessment in the Classroom: Vygostkian Praxis for Second Language Development." In Language Teaching Research, 15/1, 2011, pp. $11-33$

Lin, William J.C. "Teaching Mandarin Tones to Adult English Speakers: Analysis of Difficulties with Suggested Remedies.” In RELC: A Journal of Language Teaching and Research, 16/2, 1985, pp.31-47

Long, Michael. "Native Speaker/Non-native Speaker Conversation and the Negotiation of Comprehensible Input." In Applied Linguistics, 4/2, 1983, pp. 126-141

Long, Michael. "The Role of Linguistic Environment in Second Language Acquisition.” In Handbook of Second Language Acquisition, edited by William C. Ritchie and Tej K. Bhatia. San Diego: Academic Press, 1996, pp. 413-468

Li, Shaofeng. "The Effectiveness of Corrective Feedback in SLA: A Meta Analysis." In Language Learning, 60/2, 2010, pp. 309-365

Lǔ, Jiàn Jì 鲁健䩀. “Duìwài hànyǔ yǔyīn jiàoxué jǐ gè jīběn wèntí de zài rènshi” 对外汉语语音教 学几个基本问题的再认识 [Rethinking a Few Basic Questions of Teaching Chinese Phonetics to Foreigners]. In Dàlǐ xuéyuàn xuébào 大理学院学报 [Journal of Dàlǐ University], 9/5, 2010, pp. 1-4

Lyster, Roy and Leila Ranta. "Corrective Feedback and Learner Uptake: Negotiation of Form in Communicative Classrooms.” In Studies in Second Language Acquisition, 19/1, 1997, p. 37-66

Lyster, Roy and Kazuya Saito. "Oral Feedback in Classroom SLA: A Meta-analysis." In Studies in Second Language Acquisition, 32, 2010, pp. 265-302

Lyster, Roy, Kazuya Saito, and Masatoshi Sato. "Oral Corrective Feedback in Second Language Classrooms.” In Language Teaching, 46/1, 2013, pp. 1-40

Mackey, Alison, Susan M. Gass, and Kim McDonough. "How Do Learners Perceive Interactional Feedback?" In Studies in Second Language Acquisition, 22/4, 2000, pp. 471-497

Mackey, Alison, Rebekha Abbuhl, and Susan M. Gass. "Interactionist Approaches." In The Routledge Handbook of Second Language Acquisition, edited by Susan M. Gass and Alison Mackey. New York: Routledge, 2012, pp. 7-24

Mackey, Alison. Input, Interaction and Corrective Feedback in L2 Learning. Oxford: Oxford University Press, 2012

Mackey, Alison and Jaemyung Goo. "Interaction Research in SLA: A Meta-analysis and Research Synthesis." In Conversational Interaction in Second Language Acquisition: A Series of Empirical Studies, edited by Alison Mackey. Oxford: Oxford University Press, 2007, pp. 407-453 Mayring, Philipp. Qualitative Inhaltsanalyse: Grundlagen und Techniken. Weinheim: Beltz, 2008 Russel, Jane and Nina Spada. "The Effectiveness of Corrective Feedback for Second Language Acquisition: A Meta Analysis of Research.” In Synthesizing Research on Language Learning and Teaching, edited by Lourdes Ortega. Amsterdam: John Benjamins, 2006, pp. 133-162 
Schmidt, Richard . "The Role of Consciousness in Second Language Learning." In Applied Linguistics, 11/2, 1990, pp.129-158

Schmidt, Richard. "Deconstructing Consciousness in Search of Useful Definitions for Applied Linguistics.” In AILA Review, 11, 1994, pp. 11-26

Schoormann, Matthias and Torsten Schlak. "Sollte korrektives Feedback 'maßgeschneidert' werden? Zur Berücksichtigung kontextueller und individueller Faktoren bei der mündlichen Fehlerkorrektur im Zweit-/Fremdsprachenunterricht." In Zeitschrift für interkulturellen Fremdsprachenunterricht: Didaktik und Methodik im Bereich Deutsch als Fremdsprache, 17/2, 2012, pp. 172-190

Sheen, Younghee. Corrective Feedback, Individual Differences and Second Language Learning. Dordrecht: Springer, 2011

Surendran, Dinoj and Gina A. Levow. "The Functional Load of Tone in Mandarin is as High as that of Vowels." 2004, University of Chicago, Computer Science Department, http://people.cs.uchicago.edu/ dinoj/research/fltonemandarin.pdf, accessed June 2014

Stack, Edward M. The Language Laboratory and Modern Language Teaching. New York: Oxford University Press, 1966

Swain, Merrill. "Communicative Competence: Some Roles of Comprehensible Input and Comprehensible Output in Its Development." In Input in Second Language Acquisition, edited by Susan M. Gass and Carolyn G. Madden. Cambridge: Newbury House Publishing, 1985, pp. 235253

Swain, Merrill. "Three Functions of Output in Second Language Learning." In Principle and Practice in Applied Linguistics: Studies in Honour of H. G. Widdowson, edited by Guy Cook and Barbara Seidlhofer. New York: Oxford University Press, 1995, pp.125-144

Swain, Merrill. "The Output Hypothesis: Theory and Research." In Handbook of Research in Second Language Teaching and Learning, edited by Eli Hinkel. New York: Routledge, 2005, pp. 471-484

Waniek-Klimczak, Ewa, Andrzej Porzuczek, and Arkadiusz Rojczyk. "Affectice Dimensions in SL Pronunciation: A Large-scale Attitude Study.” In The Affective Dimension in Second Language Acquisition, edited by Danuta Gabryś-Barker and Joanna Bielska. Bristol: Multilingual Matters, 2013, pp. $124-137$

Woo, William. "A Musical Approach to Tone Teaching in Mandarin." In Journal of the Chinese Language Teachers Association, 11/2, 1976, pp. 96-102

Yáng, Jízhōu 杨寄洲. Hànyǔ jiàochéng 汉语教程 [Mandarin Chinese Course]. Běijīng 北京: Béijingng yǔyán wénhuà dàxué chūbăn shè 北京语言文化大学出版社, 2007

Yáng, Xuěméi 楊雪梅. Hànyǔ tīnglì jiàochéng 汉语听力教程 [Chinese Listening Course]. Běijīng 北京: Běijīng yǔyán wénhuà dàxué chūbăn shè 北京语言文化大学出版社, 2000

Zhang, Zhen F. The Teaching of Mandarin Prosody: A Somatically-enhanced Approach for Second Language Learners. Ph.D. Thesis, University of Canberra, 2006

Zhang, Yao. Learn Chinese Tones with Music. DVD, Quick Mandarin, 2011

Zhōu, Jiàn 周健. Hànyǔ kètáng jiàoxué jìqiǎo 325 lì 汉语课堂教学技巧 325 例 [Chinese Classroom Teaching Skills 325 Examples]. Běijīng 北京: Shāngwù Yìnshūguăn 商务印书馆, 2009

Zhōu, Xiăobīng 周小兵. Duìwài hànyǔ jiàoxué dăolùn 对外汉语教学导论 [Introduction to Teaching Chinese as a Foreign Language]. Běijīng 北京: Shāngwù Yìnshūguăn 商务印书馆, 2009 


\section{GLOSSARY}

$\begin{array}{ll}\text { bú shì } & \text { 不是 } \\ \text { qǔng zhùyì } & \text { 请注意 } \\ \text { Wǒ èrshíyĩ suì } & \text { 我二十岁 } \\ \text { Wǒ shǔ gǒu de } & \text { 我属狗的 } \\ \text { Wǒ shǔ mă de } & \text { 我属马的 } \\ \text { Wǒ shǔ shé de } & \text { 我属蛇的 } \\ \text { yáng qiāng yáng } & \text { 洋腔洋调 } \\ \text { diào } & \\ \text { yīnjié jiàoxué } & \text { 音节教学 } \\ \text { yǔliú jiàoxué } & \text { 语流教学 } \\ \text { yǔsù jiàoxué } & \text { 语素教学 }\end{array}$

'not'

'attention, please'

I am twenty-one years old I am a dog (in Chinese astrology)

I am a horse (in Chinese astrology)

I am a snake (in Chinese astrology)

'typical' foreign accent when speaking Chinese

Method of teaching phonetics using syllable instruction

Method of teaching phonetics using speechflow instruction

Method of teaching phonetics using phonemic instruction 